\title{
IGF-I Transcript Levels in Whole-LiverTissue, in Freshly Isolated Hepatocytes, and in Cultured Hepatocytes from Lean and Obese Zucker Rats
}

\author{
S. Tenoutasse ${ }^{a} \quad$ G. Van Vliet ${ }^{a, b} \quad$ E. Ledru ${ }^{a} \quad$ C. Deal ${ }^{a, b}$ \\ aResearch Unit on the Biology of Reproduction and Development, Research Center, Ste-J ustine Hospital, and \\ bepartment of Pediatrics, University of Montreal, Montreal, Que., Canada
}

\section{Key Words}

IGF-I mRNA • IGF-IB mRNA • Obesity · Zucker rat • Growth

\begin{abstract}
Background: The mechanisms underlying the maintenance of normal to high rates of linear growth and plasma insulin-like growth factor I (IGF-I) levels in spite of a low growth hormone secretion in obese children remain unknown. Among the animal models of early-onset obesity, obese Zucker (fa/fa) rats (which are homozygous for an inactivating missense mutation in the leptin receptor) are particularly appropriate, because their linear growth shows this growth hormone independence. Methods: To study the regulation of IGF-I synthesis in this model, we have established primary cultures of hepatocytes derived from 12-week-old Zucker male obese and lean rats. The rat IGF-I gene contains six exons, and alternative splicing generates different mRNAs, one of which (called IGF-1B) has been shown to be decreased by fasting. We report steady state mRNA levels for IGF-I (all transcripts) and for IGF-IB in hepatocytes after 3 days in culture, in freshly isolated hepatocytes, and in whole-liver tissue. RT-PCRs using primers specific for IGF-I or IGF-IB were performed with two different internal competitors for quantification. Results: In primary cultures of hepato-
\end{abstract}

\section{KARGER}

Fax +41613061234 E-Mail karger@karger.ch www.karger.com
(C) 2003 S. Karger AG, Basel

0301-0163/03/0593-0135\$19.50/0

Accessible online at: www. karger.com/hre cytes, the IGF-IB mRNA was increased by $>50$-fold ( $p=$ 0.01 ) in cells derived from obese animals as compared with cells from lean animals. However, these transcript levels were not significantly different when measured in freshly isolated hepatocytes or in whole-liver tissue. Conclusions: Increased IGF-IB transcription could be an intrinsic characteristic of cultured hepatocytes harbouring leptin receptors that bear the fa mutation. However, the modulation of this characteristic by cell-cell interactions and by in vivo hormone and metabolic status remains to be studied.

Copyright @2003S. Karger AG, Basel

\section{Introduction}

Childhood-onset obesity is characterized by normal to high rates of linear growth and plasma insulin-like growth factor I (IGF-I) levels in spite of low growth hormone $(\mathrm{GH})$ secretion. The mechanisms underlying this $\mathrm{GH}$ independent growth in obesity are unknown. Although multiple tissues are capable of IGF-I synthesis, the major source of circulating IGF-I in rats is the liver [1]. Liver IGF-I synthesis is stimulated by $\mathrm{GH}$ and requires sufficient caloric intake [2]. Specifically, fasting and undernutrition result in decreased serum IGF-I levels in humans and rats and in decreased liver IGF-I messenger RNA
Cheri Deal, PhD, MD

Endocrine Service, Room 1706, Ste-Justine Hospital

3175 Côte Ste-Catherine

Montréal, Qué. H3T-1C5 (Canada)

Tel. +1 514345 4735, Fax +1 514345 4988, E-Mail Cheri.L.Deal@umontreal.ca 
Table 1. Primers used in RT-PCR for IGF-I and IGF-IB

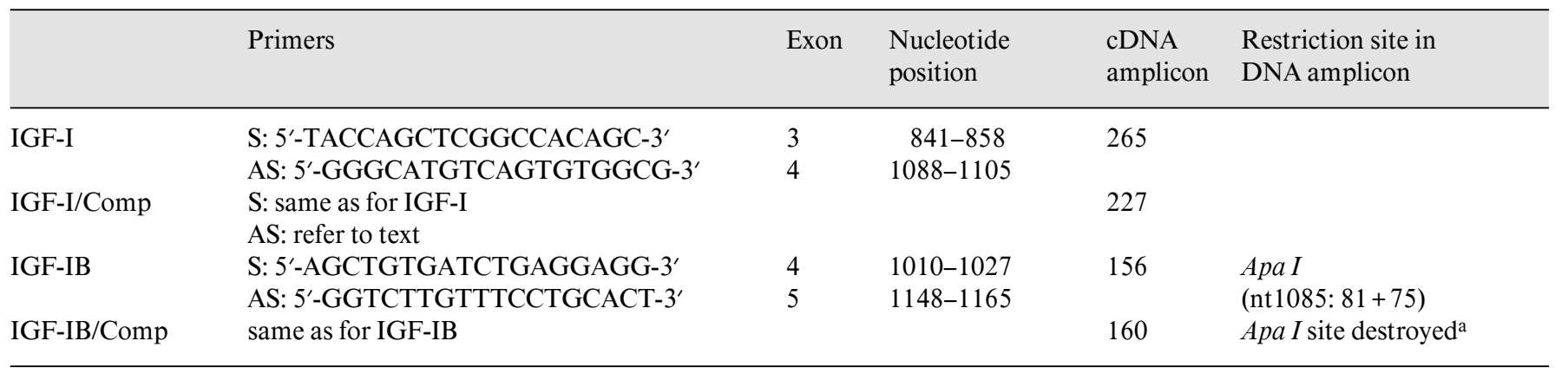

Comp = Competitor; $\mathrm{S}=$ sense; $\mathrm{AS}=$ antisense; ${ }^{\text {a }}$ refer to text for in vitro mutagenesis details.

(mRNA) concentrations in rats [3]. In contrast, situations of 'overnutrition' such as obesity have received little attention.

The rat IGF-I gene is comprised of 6 exons, with exons 3 and 4 coding for the mature IGF-I peptide $[4,5]$. Alternative splicing results in two mRNAs differing by the presence (IGF-IB) or absence (IGF-IA) of exon 5 (which contains $52 \mathrm{bp}$ ). Moreover, transcription can start at exon 1 or 2 , and there is a long 3 -untranslated region with multiple polyadenylation sites on exon 6 . The generation of multiple mRNAs, with potentially different posttranscriptional fates, provides one of the possible mechanisms that regulate IGF-I synthesis. Zhang et al. [3] have shown that fasting specifically decreases IGF-IB transcript levels in the rat liver without changing IGF-IA.

In the obese Zucker rat $(f a / f a)$, obesity is inherited as an autosomal recessive trait and is due to an inactivating mutation of the leptin receptor; this results in severe leptin resistance [6]. It is, therefore, a model for human obesity which is most often associated with leptin resistance [7]. In addition, we have shown that $f a / f a$ rats also show GH-independent growth [8]. Previous studies [9, 10] have demonstrated that hepatocytes from $f a / f a$ rats maintain a distinct phenotype after removal from their in vivo environment for 8 days. It is, therefore, conceivable that increased IGF-I synthesis is an intrinsic characteristic of hepatocytes derived from $f a / f a$ rats. To evaluate this, we have developed semiquantitative RT-PCR methods with internal competitors for both total IGF-I and IGF-IB transcript levels in primary cultures of hepatocytes $(\mathrm{PCH})$ from male obese $(f a / f a)$ and lean $(F a /$ ?) Zucker rats. We also measured steady state IGF-I and IGF-IB mRNAs in the whole liver (flash frozen immediately after sacrifice) and in freshly isolated hepatocytes.

\section{Materials and Methods}

\section{Animals and Experimental Design}

Twelve-week-old male Zucker rats ( $f a / f a$ and $\mathrm{Fa} /$ ?) were purchased from Charles River Canada (Saint-Constant, Qué., Canada) and individually housed on a 12-hour light, 12-hour dark cycle in a temperature- and humidity-controlled room. Lean (control) rats are referred to as $\mathrm{Fa} /$ ? and were not separated by genotype $(\mathrm{Fa} / \mathrm{Fa}$ and $\mathrm{Fa} / \mathrm{fa}$ ). All rats were fed ad libitum, until $16 \mathrm{~h}$ before manipulation. The study protocol was approved by the local animal research ethics committee.

Hepatocytes were collected after in situ liver perfusion with collagenase according to the method of Seglen [11]. If the cell viability (evaluated by trypan blue exclusion) was $65 \%$ or more, the cells were put on Petri plates $\left(3 \times 10^{6}\right.$ viable cells/dish $)$ in $3 \mathrm{ml}$ of medium. The cells were grown at $37^{\circ} \mathrm{C}$ in a humidified atmosphere containing $5 \%$ $\mathrm{CO}_{2}$ in DMEM-F12 medium supplemented with $\mathrm{T}_{3}\left(1 \times 10^{-9} M\right)$, hydrocortisone $\left(5 \times 10^{-8} M\right)$, ethanolamine $\left(1 \times 10^{-6} M\right)$, ornithine $\left(4 \times 10^{-4} M\right)$, selenium $\left(2.5 \times 10^{-8} M\right)$, lactic acid $\left(1.8 \times 10^{-5} M\right)$, and penicillin/streptomycin/Fungizone $(100 \mathrm{U} / \mathrm{ml}, 100 \mu \mathrm{g} / \mathrm{ml}$, and $0.25 \mu \mathrm{g} / \mathrm{ml}$, respectively). For $20 \mathrm{~h}$ following plating, the medium was also supplemented with $10 \%$ fetal bovine serum; the medium was changed after the first $4 \mathrm{~h}$ to remove unattached cells [see 29]. Thereafter, the serum-free medium was changed daily, and insulin $(1.75 \times$ $\left.10^{-7} \mathrm{M}\right)$ and bovine serum albumin $(0.5 \%)$ were added for an additional $24 \mathrm{~h}$. A previous report [12] has shown that between 48 and $96 \mathrm{~h}$, the hepatocytes are well attached and preserve differentiated function; therefore, the cells were harvested after $72 \mathrm{~h}$ (in the absence of serum or insulin for the last $24 \mathrm{~h}$ ) for RNA extraction.

Isolated hepatocytes were also obtained immediately after in situ liver perfusion with collagenase and were frozen until RNA extraction. For whole-liver investigations, the rats were dissected quickly after sacrifice, and liver tissue was flash frozen in liquid nitrogen until RNA extraction.

Total RNA was extracted with the guanidinium method, as previously described [13]. A supplementary step of delipidation was performed on hepatocytes from $f a / f a$ rats, as detailed by Louveau et al. [14]. The total RNA concentration was measured spectrophotometrically (at $260 \mathrm{~nm}$ of absorbance).

\section{Quantification of $m R N A s$ by RT-PCR}

One microgram of total RNA was reverse transcribed by random priming using M-MLV Reverse Transcriptase (Invitrogen Life Tech- 
nologies, Burlington, Ont., Canada) in a final volume of $30 \mu \mathrm{l}$, as previously described [15]. The absence (IGF-IA) or presence (IGFIB) of a 52-bp insert in rat IGF-I transcripts [16] allowed amplification of both IGF-IA and IGF-IB by RT-PCR with one primer pair and of IGF-IB specifically with a second primer pair. Primers were composed of 18 nucleotides each (table 1) according to the gene sequence established by Shimatsu and Rotwein [17] in 1987 and extended in 1992 [18].

Competitive PCR, with separation of PCR products by electrophoresis on a polyacrylamide gel ( $7 \%$ for IGF-I and $10 \%$ for IGF-IB), was used to quantitate specific transcripts. The IGF-I competitor was constructed as described by Forster [19] (sense primer as for IGF-I, table 1; antisense primer: CAGTGTGGCGAGGCTTGCAGCGGACACA). IGF-I and IGF-I competitor were distinguished by virtue of their different lengths (265 and $227 \mathrm{bp}$, respectively). The internal competitor for IGF-IB was constructed by in vitro mutagenesis [20], resulting in the destruction of a restriction site in the amplicon (Apa I site). Digestion with Apa I thus allowed us to distinguish IGF-IB competitor (not cleaved) and our fragment of interest (cleaved; see table 1). Plasmids containing the competitor were diluted to concentrations ranging from 0.1 to $10 \times 10^{-4} \mathrm{fM}$ for IGF-I and for IGF-IB.

The cDNA and the competitor were mixed with sense and antisense primers ( $100 \mathrm{p} M$ each) in the buffer supplied by Invitrogen Life Technologies and $0.1 \mathrm{~m} M$ dNTP including $1 \mu \mathrm{Ci}$ of $\left[\alpha-{ }^{32} \mathrm{P}\right] \mathrm{dATP}$ (Amersham Life Science, Oakville, Ont., Canada), $2 \mathrm{mM} \mathrm{MgCl}$, and $2 \mathrm{U}$ of Taq DNA polymerase (Life Technologies) in a final volume of $25 \mu \mathrm{l}$. PCR amplifications were performed with $1.25 \mu \mathrm{l}$ of the reverse transcription product and were carried out at $94^{\circ} \mathrm{C}$ for $25 \mathrm{~s}$, at $60^{\circ} \mathrm{C}$ for $25 \mathrm{~s}$, and at $72^{\circ} \mathrm{C}$ for $90 \mathrm{~s}$ for a total of 30 cycles for IGF-I and at $94^{\circ} \mathrm{C}$ for $25 \mathrm{~s}$, at $58^{\circ} \mathrm{C}$ for $25 \mathrm{~s}$, and at $72^{\circ} \mathrm{C}$ for $90 \mathrm{~s}$ for a total of 30 cycles for IGF-IB. GAPDH was used as a housekeeping gene as previously described [16].

\section{Statistics}

The data were quantified by image analysis with a PhosphorImager (Molecular Dynamics, Sunnyvale, Calif., USA). The results are presented as mean values \pm SD or as median and range, and the data obtained from $f a / f a$ and $F a /$ ? were compared by the Student's $t$ test or by the Mann-Whitney test as appropriate. The level of significance was set at 0.05 .

\section{Results}

\section{Weight}

As expected for male Zucker rats at 12 weeks of age, $\mathrm{fa} / \mathrm{fa}$ animals had a mean weight on average 1.33 -fold higher than that of $\mathrm{Fa}$ /? animals (450.4 $\pm 67.5 \mathrm{~g}, \mathrm{n}=5$, vs. $337.8 \pm 25.3 \mathrm{~g}, \mathrm{n}=7 ; \mathrm{p} \leq 0.005)$.

\section{IGF-I and IGF-IB mRNA in Hepatocytes from $\mathrm{fa} / \mathrm{fa}$ and $\mathrm{Fa} /$ ? Animals}

Similar amounts of total RNA were obtained from PCH derived from $f a / f a$ and $F a / ?$ animals $(11.4 \pm 5.6 \mu \mathrm{g} /$ Petri dish, $\mathrm{n}=5$, vs. $13.2 \pm 5.5 \mu \mathrm{g} /$ Petri dish, $\mathrm{n}=7$; NS). Both total IGF-I mRNA and IGF-IB mRNA and their

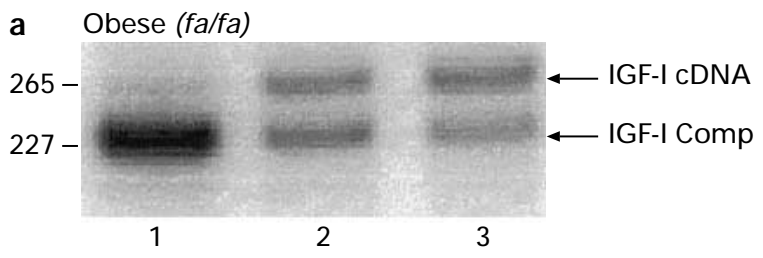

b Lean (Fa/?)
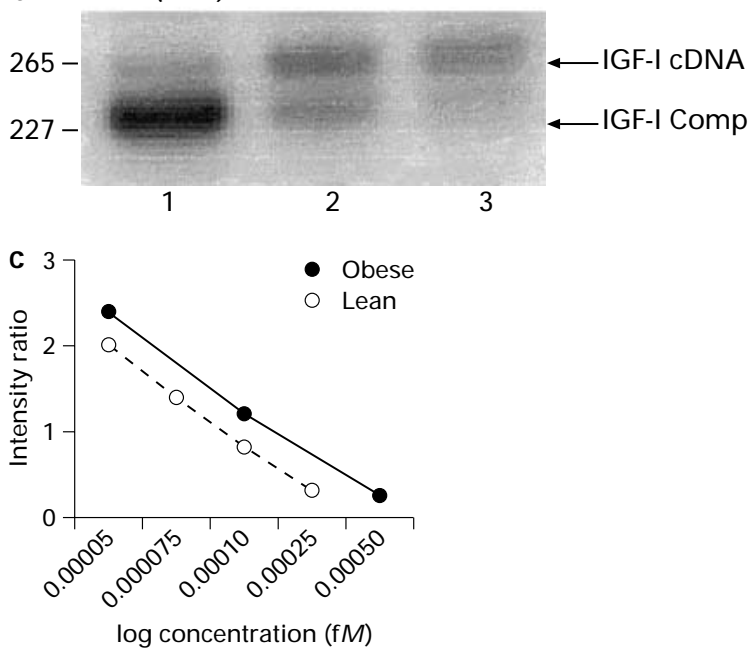

Fig. 1. IGF-I mRNA in hepatocytes after 3 days in primary culture. Hepatocytes derived from a representative $f a / f a$ animal (a) and from a representative $\mathrm{Fa} /$ ? animal (b). Competitor (Comp) concentrations: lane $1,5 \times 10^{-4} \mathrm{fM}$; lane $2,1 \times 10^{-4} \mathrm{fM}$; lane $3,0.5 \times$ $10^{-4} \mathrm{f} M$. c IGF-I competition curve. The $\mathrm{x}$ axis indicates the $\log _{10}$ of the concentration of internal standard added for coamplification, and the $y$ axis indicates the ratio of the intensity of the specific IGF-I PCR product to that of the internal standard.

respective competitors were well amplified at the chosen concentrations of competitors in cells from both phenotypes (fig. 1,2). Table 2 shows the results of quantification: in hepatocytes from $f a / f a$ animals, both IGF-I and IGF-IB mRNA levels were higher than in hepatocytes from $\mathrm{Fa}$ /? animals; however, the difference in median levels was only 1.7-fold for total IGF-I mRNA (NS), while it was marked $(>50$-fold) and significant $(p=0.01)$ for IGFIB mRNA.

\section{$I G F-I$ and IGF-IB mRNAs in Isolated Hepatocytes and Whole Liver}

Our results obtained in $\mathrm{PCH}$ were, surprisingly, not consistent with those reported previously by Melián et al. [23] who observed a decreased IGF-1 mRNA expression in liver and other tissues in the male Zucker fatty rat. We, therefore, decided to investigate freshly isolated hepato- 


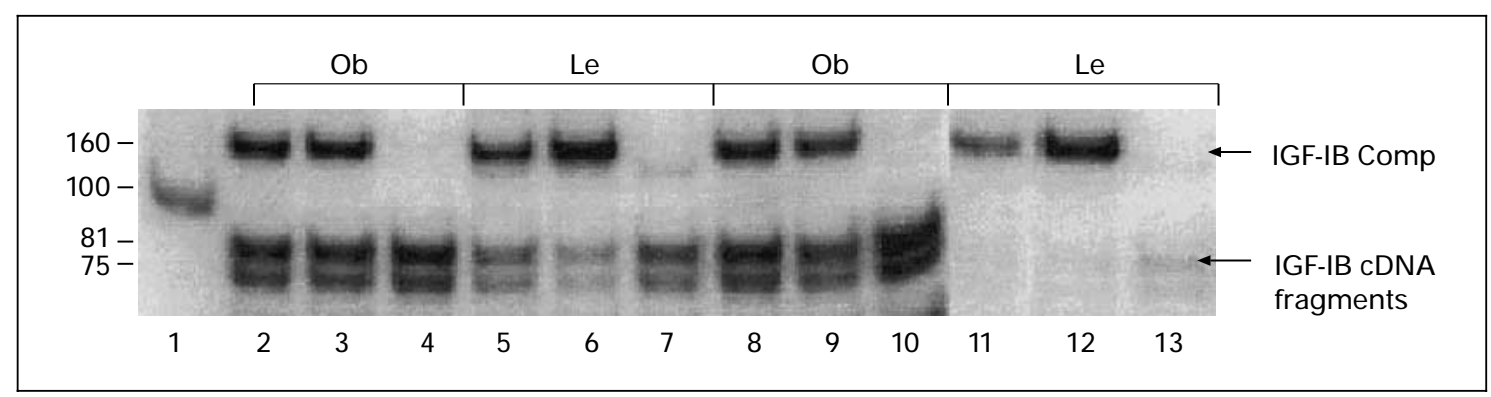

Fig. 2. IGF-IB mRNA expression in hepatocytes after 3 days in primary culture. As described in Materials and Methods, the expression levels were determined by PhosphorImager analysis of the PCR products after Apa 1 digestion. Two representative animals from each group $(\mathrm{Ob}=f a / f a$ and $\mathrm{Le}=F a /$ ? $)$ are shown. Lane 1, DNA ladder. Competitor (Comp) concentrations: lanes 2 and 8, $1.0 \times 10^{-4} \mathrm{fM}$; lanes 3, 6, 9, and 12, $0.5 \times 10^{-4} \mathrm{fM}$; lanes 5 and 11, $0.1 \times 10^{-4} \mathrm{f} M$; lanes $4,7,10$, and 13 , no internal competitor added.

Table 2. IGF-I and IGF-IB steady-state mRNA levels in hepatocytes after three days in primary culture

\begin{tabular}{llll}
\hline & $\begin{array}{l}\text { Obese }(f a / f a) \\
(\mathrm{n}=5)\end{array}$ & $\begin{array}{l}\text { Lean }(\mathrm{Fa} / \text { ? }) \\
(\mathrm{n}=7)\end{array}$ & \\
\hline $\begin{array}{l}\text { IGF-I mRNA } \\
\text { Median }\end{array}$ & 20.9 & 12.4 & $\mathrm{p}>0.2$ \\
$\quad \begin{array}{l}\text { Range } \\
\text { IGF-IB mRNA }\end{array}$ & $4.3-230.4$ & $1.0-18.8$ & \\
$\quad$ Median & 92.0 & 1.6 & $\mathrm{p}=0.01$ \\
$\quad$ Range & $4.1-1,724.3$ & $1.1-5.4$ & \\
\hline
\end{tabular}

Results were normalized with GAPDH; mRNA levels and relative abundance of mRNA expressed in arbitrary units.

cytes and whole-liver tissue from obese and lean Zucker rats. Quantification of total IGF-I mRNA and IGF-IB mRNA was performed on isolated hepatocytes (obtained just after the in situ liver perfusion) and on whole-liver tissue. The results are summarized in table 3. The mRNA levels for both total IGF-I and for IGF-IB were lower in whole-liver tissue and in freshly isolated hepatocytes obtained from $f a / f a$ rats than in liver tissue and hepatocytes obtained from $\mathrm{Fa}$ ? ? rats.

\section{Discussion}

In hepatocytes from 12-week-old male $f a / f a$ rats maintained in primary cultures for 3 days, we observed a greater than 50-fold increase in IGF-IB mRNA levels as compared with the levels in cells derived from $F a /$ ? rats $(\mathrm{p}=$
Table 3. IGF-I and IGF-IB steady state mRNA levels in freshly isolated hepatocytes and in whole-liver tissue

\begin{tabular}{llll}
\hline & Obese $(\mathrm{fa} / \mathrm{fa})$ & Lean $(\mathrm{Fa} /$ ? $)$ & \\
\hline $\begin{array}{l}\text { Freshly isolated hepatocytes } \\
\text { IGF-I mRNA }\end{array}$ & & \\
$\quad$ Median & 1.0 & 2.4 & \\
$\quad$ Range & $1.0-1.0$ & $1.8-3.0$ & \\
IGF-IB mRNA & & & \\
$\quad$ Median & 6.7 & 8.8 & \\
$\quad$ Range & $4.8-8.7$ & $7.4-10.2$ & \\
\hline $\begin{array}{l}\text { Whole-liver tissue } \\
\text { IGF-I mRNA }\end{array}$ & & & \\
$\quad$ Median & 4.1 & 10.4 & \\
$\quad$ Range & $2.5-5.7$ & $7.4-13.1$ & \\
IGF-IB mRNA & & & \\
$\quad$ Median & 1.9 & 3.7 & \\
$\quad$ Range & $1.3-2.3$ & $3.4-4.0$ & \\
\hline
\end{tabular}

Results were normalized with GAPDH; mRNA levels and relative abundance of mRNA expressed in arbitrary units; the median of samples from 2 animals for the freshly isolated hepatocytes and from 3 animals for the whole-liver tissue is shown.

$0.01)$. However, the increase in total IGF-I mRNA was much more modest (1.7-fold) and did not reach statistical significance. It has been estimated that, in liver extracts from 5-week-old Sprague-Dawley rats, IGF-IB mRNA amounts to about $23 \%$ of total IGF-I mRNA [3]. It is, therefore, likely that a compensatory decrease of IGF-IA mRNA transcripts would be observed in hepatocytes from $f a / f a$ rats. Fasting has been shown to decrease the steady state levels of IGF-IB mRNA in the liver by post- 
transcriptional mechanisms [21]; it will be important, therefore, to compare posttranscriptional steps in cells from $\mathrm{fa} / \mathrm{fa}$ and $\mathrm{Fa} /$ ? rats. Moreover, the relative contributions of the various IGF-I mRNA transcripts to the secreted IGF-I protein are unknown. While increased IGF-I peptide synthesis does not necessary follow from increased steady state IGF-I mRNA, it is noteworthy that the difference in plasma IGF-I concentrations between $\mathrm{fa}$ / $f a$ and $F a /$ ? male rats ( $\sim 1.15$ fold) [8] is of the same order of magnitude as the difference observed here for total IGF-I mRNA ( $\sim 1.7$ fold $)$. On the other hand, steady state IGF-I and IGF-IB mRNA levels measured in freshly isolated hepatocytes and in whole-liver tissue followed a different pattern: both total IGF-I mRNA and IGF-IB mRNA levels were slightly decreased in the obese rats.

Increased IGF-IB mRNA levels in PCH could be an indirect consequence of the abnormal morphology of cultured $f a / f a$ hepatocytes. Indeed, $f a / f a$ hepatocytes remain lipid laden with microvesicular steatosis as compared with $\mathrm{Fa} /$ ? controls, even after 3 days in culture ([22] and our own results). This required subjecting $f a / f a$ cells to a delipidation step which resulted in similar RNA yields for cells of both phenotypes.

Our results using hepatocytes in culture contrast with those of Melián et al. [23] who used a ribonuclease protection assay to study whole-liver tissue mRNA. These investigators reported decreased IGF-I and IGF-IB mRNA levels in 6- and 11-week-old $f a / f a$ rats as compared with lean controls. We have confirmed their findings using competitive RT-PCR of total RNA extracted from whole-liver tissue (table 3 ), as well as on poly(A)+-enriched RNA (data not shown). Furthermore, we have shown that IGF-I and IGF-IB transcripts are similarly decreased in freshly isolated hepatocytes and in whole-liver tissue from obese rats (table 3). It should be noted that hepatocytes, the major producers of IGF-I in the liver, account for only $65 \%$ of its cell population. In cultures of non-parenchymal liver cells, IGF-I mRNA has also been detected in Kupffer cells, endothelial cells, and hepatic stellate cells [24, 25]. Finally, cell-to-cell communication in the liver [26] and the in vivo hormonal milieu (which is characterized by massive hyperinsulinism) are likely important for the ultimate determination of the amount of IGF-I peptide secreted. It is, therefore, not surprising that the differences in IGF transcript levels between obese and lean animals may be in opposite directions, depending on whether one uses cultured hepatocytes, freshly isolated hepatocytes, or whole-liver tissue.

Our finding that hepatocytes from $\mathrm{fa} / \mathrm{fa}$ vs $\mathrm{Fa} /$ ? rats, under the culture conditions described, contain markedly increased levels of IGF-IB mRNA is consistent with the concept that these cells maintain different phenotypes in vitro; this concept is also supported by the observation of others regarding the metabolism of lipids [27], carbohydrates [10, 38], and proteins [9]. These different phenotypes persist until at least 9 days in culture, as shown by the maintenance of an increased capacity for fat storage by $f a / f a$ adipocytes [28]. Interestingly, even hepatocytes derived from Zucker rats at the fetal stage (i.e., prior to the development of the obese phenotype) display different biochemical (but not morphological) characteristics, depending on the presence or absence of the fa mutation [9]. Thus, an increased steady state IGF-IB mRNA expression, rather than being due to an indirect effect of cellular steatosis, could be an intrinsic property of hepatocytes bearing the $f a$ mutation, but can only be evidenced when hepatocytes are cultured for 3 days and, therefore, no longer exposed to the in vivo hormonal influences[29].

The $f a$ mutation is an A-to-C transversion at nucleotide 800 , resulting in a Gln269Pro substitution mutation of the leptin receptor gene $(o b-r)$ [6]. Expression studies in transfected cells have shown that the number of mutant OB-R ${ }^{\text {Gln269Pro }}$ on the cell surface is four- to tenfold lower than the number of wild-type receptors; whether leptin resistance also involves an intrinsic defect in the signaling capacity of OB-R ${ }^{\text {Gln269Pro }}$ remains controversial [30, 31]. $o b-r$ is a single gene, encoding at least five protein isoforms; the long form, called OB-Rb, is thought to mediate the cellular response to leptin, whereas a short form, called OB-Ra, with a truncated intracellular domain, may be involved in leptin transport and/or clearance [32, 33].

$\mathrm{OB}-\mathrm{Rb}$ is most abundantly expressed in the choroid plexus and in the arcuate nucleus, where leptin exerts its main biological function on food intake. However, leptin also directly induces physiological responses in peripheral tissues, even in those that do not express detectable levels of Ob-Rb [34, 35]. Cohen et al. [36] showed direct antiinsulin effects of leptin in human and rat hepatoma cell lines, while Aiston and Agius [37] and Aiston et al. [38] suggested a direct insulin-like physiological effect of leptin on glycogen storage in untransformed rat hepatocytes. It is conceivable that inactivation of the leptin receptor by the $f a$ mutation could be the direct cause of increased IGF-IB transcript levels in hepatocytes bearing this mutation.

In summary, we have shown that the steady state IGFIB mRNA levels are strikingly elevated in hepatocytes derived from adult male $f a / f a$ rats as compared with cells from $\mathrm{Fa} /$ ? controls after primary culture for 3 days, while they are slightly decreased in freshly isolated hepatocytes 
and in whole-liver tissue. Whether this intrinsic characteristic of $f a / f a$ hepatocytes in culture is a direct consequence of the leptin receptor mutation or an indirect consequence of abnormal hepatocyte metabolism remains to be determined. Liver-derived IGF-I does not appear to be essential for normal growth in mice [39]. However, the liver is the primary source of circulating IGF-I in rats [1], and we speculate that increased IGF-IB transcription in $f a / f a$ hepatocytes may play a role in the $\mathrm{GH}$-independent growth of obese Zucker rats.

\section{Acknowledgments}

This work was supported by a grant from the Canadian Diabetes Association (to G.V.V. and C.D.). Dr. S. Tenoutasse was supported by an ESPE Research Fellowship, sponsored by Novo Nordisk. Dr. Cheri Deal is a research scholar of the Fonds de la Recherche en Santé du Québec.

\section{References}

1 Schwander JC, Hauri C, Zapf J, Froesch ER: Synthesis and secretion of insulin-like growth factor and its binding protein by the perfused rat liver: Dependence on growth hormone status. Endocrinology 1983;113:297-305.

2 Thissen JP, Ketelslegers JM, Underwood LE: Nutritional regulation of the insulin-like growth factors. Endocr Rev 1994;15:80-101.

3 Zhang J, Whitehead RE Jr, Underwood LE: Effect of fasting on insulin-like growth factor-I (IGF-1) A and IGF-1B messenger ribonucleic acids and prehormones in rat liver. Endocrinology 1997;138:3112-3118.

4 Daughaday WH, Rotwein P: Insulin-like growth factors I and II: Peptide, messenger ribonucleic acid and gene structures, serum, and tissue concentrations. Endocr Rev 1989; 10:68-91

5 Hoyt EC, Hepler JE, Van Wyk JJ, Lund PK: Structural characterization of exon 6 of the rat IGF-I gene. DNA Cell Biol 1992;11:433-441.

6 Phillips MS, Liu Q, Hammond HA, Dugan V, Hey PJ, Caskey TC, Hess JF: Leptin receptor missense mutation in the fatty Zucker rat. Nat Genet 1996;13:18-19.

7 Considine RV, Sinha MK, Heiman ML, Kriauciunas A, Stephens TW, Nyce MR, Ohannesian JP, Marco CC, McKee LJ, Bauer TL, Caro JF: Serum immunoreactive-leptin concentrations in normal-weight and obese humans. $\mathrm{N}$ Engl $\mathrm{J}$ Med 1996;334:292-295.

8 Nguyen-Yamamoto L, Deal CL, Finkelstein JA, Van Vliet G: Hormonal control of growth in the genetically obese Zucker rat. I. Linear growth, plasma insulin-like growth factor-I (IGF-I) and IGF-binding proteins. Endocrinology 1994;134:1382-1388.

9 Goldstein AL, Johnson PR: Primary cultures of fetal hepatocytes from the genetically obese Zucker rat: Characterization and total lipogenesis. In Vitro 1980;16:288-296.

10 García-Sainz JA, Alántrara-Hernández R, Robles-Flores M, Torres-Márquez ME, Massillon D, Annabi B, Van de Werve G: Modulation by protein kinase $\mathrm{C}$ of the hormonal responsiveness of hepatocytes from lean $(\mathrm{Fa} / \mathrm{fa}$ ?) and obese (fa/fa) Zucker rats. Biochim Biophys Acta 1992;1135:221-225.
11 Seglen PO: Preparation of isolated liver cells. Methods Cell Biol 1976;13:29-83.

12 Kachra Z, Yang CR, Murphy LJ, Posner BI: The regulation of insulin-like growth factorbinding protein 1 messenger ribonucleic acid in cultured rat hepatocytes: The roles of glucagon and growth hormone. Endocrinology 1995; 135:1722-1728.

13 Chomczynski P, Sacchi N: Single-step method of RNA isolation by acid guanidinium thiocyanate-phenol-chloroform extraction. Anal Biochem 1987;162:156-159.

14 Louveau I, Chaudri S, Etherton TD: An improved method for isolating RNA from porcine adipose tissue. Anal Biochem 1991;196:308331.

15 Paquette J, Giannoukakis N, Polychronakos C, Vafiadis P, Deal C: The INS 5' variable number of tandem repeats is associated with $I G F 2$ expression in humans. J Biol Chem 1998;273: 14158-14164.

16 Roberts CT Jr, Lasky SR, Lowe WL Jr, Seaman WT, Le Roith D: Molecular cloning of rat insulin-like growth factor I complementary deoxyribonucleic acids: Differential messenger ribonucleic acid processing and regulation by growth hormone in extrahepatic tissues. Mol Endocrinol 1987;1:243-248.

17 Shimatsu A, Rotwein P: Mosaic evolution of the insulin-like growth factor-I factors: Organization, sequence and expression of the rat insulin-like growth factor 1 gene. J Biol Chem 1987; 262:7894-7900.

18 Hall LJ, Kajimoto Y, Bichell D, Kim SW, James PL, Counts D, Nixon LJ, Tobin G, Rotwein P: Functional analysis of the rat insulinlike growth factor 1 gene and identification of an IGF-1 gene promoter. DNA Cell Biol 1992; 11:301-313.

19 Forster E: Rapid generation of internal standards for competitive PCR by low-stringency primer annealing. Biotechniques 1994;16: 1006-1008.
20 Tang J, Lagace G, Collu R: Simple method for constructing internal standards for competitive PCR. Biotechniques 1996;21:378-380.

21 Zhang J, Chrysis D, Underwood LE: Reduction of hepatic insulin-like growth factor-I (IGF-I) messenger ribonucleic acid (mRNA) during fasting is associated with diminished splicing of IGF-1 pre-mRNA and decreased stability of cytoplasmic IGF-I mRNA. Endocrinology 1998;139:4523-4523.

22 Wang SR, Infante J, Catala D, Petit D, Bonnefis MT, Infante R: Lipid and lipoprotein synthesis in isolated and cultured hepatocytes from lean and obese Zucker rats. Biochim Biophys Acta 1989;1002:302-311.

23 Melián E, Gonzalez B, Ajo R, Gonzalez N, Sanchez Franco F: Tissue-specific response of IGF-I mRNA expression to obesity-associated $\mathrm{GH}$ decline in the male Zucker fatty rat. J Endocrinol 1999;160:49-56.

24 Scharf JG, Knittel T, Dombrowski F, Müller L, Saile B, Braulke T, Hartmann H, Ramadori G: Characterization of the IGF axis components in isolated rat hepatic stellate cells. Hepatology 1998:27:1275-1284.

25 Uchijima Y, Takenaka A, Takahashi S, Noguchi T: Production of insulin-like growth factors and their binding proteins in primary cultures of rat liver parenchymal and nonparenchymal cells. Biosci Biotechnol Biochem 1995;59: 1503-1515.

26 Clement B, Gripon P, Guguen-Guillouzo C, Guillouzo A: Interaction of cells and extracellular matrix in the liver; in Bioulac-Sage P, Balabaud $C$ (eds): Sinusoids in Human Liver: Health and Disease. Leiden, The Kupffer Cell Foundation, 1988, pp 111-137.

27 Bourgeois C, Wiggins D, Hems R, Gibbons GF: VLDL output by hepatocytes from obese Zucker rats is resistant to the inhibitory effect of insulin. Am J Physiol 1995;269:E208E215.

28 Briquet-Laugier V, Dugail I, Ardouin B, Le Liepvre X, Lavau M, Quignard-Boulange A: Evidence for a sustained genetic effect on fat storage capacity in cultured adipose cells from Zucker rats. Am J Physiol 1994;267:E439E446. 
29 Denver RJ, Nicoll CS: Pancreatic hormones differentially regulate insulin-like growth factor (IGF)-I and IGF-binding protein production by primary rat hepatocytes. J Endoccrinol 1994;142:299-310.

30 Rosenblum CI, Tota M, Cully D, Smith T, Collum R, Qureshi S, Hess JF, Phillips MS, Hey PJ, Vongs A, Fong TM, Xu L, Chen HY, Smith RG, Schindler C, Van der Ploeg LH: Functional STAT 1 and 3 signaling by leptin receptor (OB-R): Reduced expression of the rat fatty leptin receptor in transfected cells. Endocrinology 1996;137:5178-5181.

31 Da Silva BA, Bjorbaek C, Uotani S, Flier JS Functional properties of leptin receptor isoforms containing the Gln $\rightarrow$ Pro extracellular domain mutation of the fatty rat. Endocrinology $1998 ; 139: 3681-3690$.
32 Tartaglia LA, Dembski, Weng X, Deng N, Culpepper J, Devos R, Richards GJ, Campfield LA, Clark FT, Deeds J, Muir C, Sanker, Moriarty A, Moore KJ, Smutko JS, Mays GG, Woolf EA, Monroe CA, Tepper RI: Identification and expression cloning of a leptin receptor, OB-R. Cell 1995;83:1263-1271.

33 Tartaglia LA: The leptin receptor. J Biol Chem 1997;272:6093-6096.

34 Hoggard N, Mercer JG, Rayner DV, Moar K, Trayhurn P, Williams LM: Localization of leptin receptor mRNA splice variants in murine peripheral tissues by RT-PCR and in situ hybridization. Biochem Biophys Res Commun 1997;232:383-387.
35 Fei H, Okano HJ, Li C, Lee GH, Zhao C, Darnell R, Friedman JM: Anatomic localization of alternatively spliced leptin receptors (Ob-R) in mouse brain and other tissues. Proc Natl Acad Sci USA 1997;94:7001-7005.

36 Cohen B, Novick D, Rubinstein M: Modulation of insulin activities by leptin. Science 1996;274:1185-1188.

37 Aiston S, Agius L: Leptin enhances glycogen storage in hepatocytes by inhibition of phosphorylase and exerts an additive effect with insulin. Diabetes 1999;48:15-20.

38 Aiston S, Peak M, Agius L: Impaired glycogen synthesis in hepatocytes from Zucker fatty $f a$ $f a$ rats: The role of increased phosphorylase activity. Diabetologia 2000;43:589-597.

39 Le Roith D, Bondy C, Yakar S, Liu JL, Butler A: The somatomedin hypothesis: 2001. Endocr Rev 2001;22:53-74 